\title{
Trichopria drosophilae (Diapriidae) and Leptopilina heterotoma (Figitidae), native parasitoids of Drosophila suzukii, confirmed in Slovenia
}

\author{
Špela MODIC ${ }^{1 *}$, Primož ŽIGON ${ }^{1}$, Jaka RAZINGER ${ }^{1}$
}

Received December 20, 2018; accepted February 13, 2019.

Delo je prispelo 20. decembra 2018, sprejeto 13. februarja 2019.

\begin{abstract}
The Spotted-wing drosophila (SWD), Drosophila suzukii (Matsumura, 1931) (Diptera, Drosophilidae) was recorded for the first time in Slovenia in autumn 2010. Shortly thereafter, it turned out to be one of the most important insect pests of soft and stone fruit in Slovenia and elsewhere. Within the expert work in the field of plant protection, more precisely within task inventarisation of beneficial organisms for biological control, the presence of indigenous $D$. suzukii parasitoids was investigated in 2018. Sentinel traps baited with D. suzukii larvae and pupae in banana slices enriched with artificial food medium for drosophilids were used for inventorying $D$. suzukii parasitoids in raspberries. The pupal parasitoid Trichopria drosophilae (Perkins, 1910) (Hymenoptera: Diapriidae) and the larval parasitoid Leptopilina heterotoma (Thompson, 1862) (Hymenoptera: Figitidae) were recorded parasitizing $D$. suzukii for the first time in Slovenia in August 2018 in Central Slovenia (Ljubljana).
\end{abstract}

Key words: Leptopilina heterotoma; Trichopria drosophilae; parasitoids; biological control; natural enemy; Drosophila suzukii; spotted wing drosophila

\section{IZVLEČEK}

Trichopria drosophilae (Diapriidae,) IN Leptopilina heterotoma (Figitidae) - PRVI NAJDBI DOMORODNIH PARAZITOIDOV PLODOVE VINSKE MUŠICE (Drosophila suzukii) V SLOVENIJI

Plodova vinska mušica (PVM), Drosophila suzukii (Matsumura, 1931) (Diptera, Drosophilidae) je bila prvič ugotovljena v Sloveniji jeseni leta 2010. Kmalu po tem se je izkazalo, da gre za enega najpomembnejših škodljivcev pri pridelavi jagodičastega in koščičastega sadja pri nas in drugod po svetu. V okviru programa strokovnih nalog s področja zdravstvenega varstva rastlin, natančneje $\mathrm{v}$ okviru naloge inventarizacija koristnih organizmov za biotično varstvo rastlin, smo v letu 2018 ugotavljali zastopanost domorodnih vrst parazitoidov plodove vinske mušice. Kot vabe za lovljenje parazitoidov PVM smo uporabljali koščke banan okužene $\mathrm{z}$ ličinkami in bubami PVM, katerim smo dodali umetni jabolčni medij za vinske mušice. Ugotovili smo, da sta pri nas zastopana larvalni parazitoid Leptopilina heterotoma (Thompson, 1862) (Hymenoptera: Figitidae) in parazitoid bub Trichopria drosophilae (Perkins, 1910) (Hymenoptera: Diapriidae). Obe vrsti sta bili ugotovljeni avgusta leta $2018 \mathrm{v}$ osrednji Sloveniji z vabami nastavljenimi v grme malin.

Ključne besede: Leptopilina heterotoma; Trichopria drosophilae; parazitoidi; biotično varstvo; naravni sovražniki; Drosophila suzukii; plodova vinska mušica

\section{INTRODUCTION}

The spotted wing drosophila, Drosophila suzukii (Matsumura, 1931), SWD, Diptera, Drosophilidae) originally reported in Japan in 1930, almost at the same time (2008) invaded North America (California) and Europe (Italy, Spain) and emerged as an alien pest of soft fruits (Cini et.al., 2012). While other Drosophila species feed on rotten and damaged fruits, D. suzukii females possess a serrated ovipositor that allows egg deposition into undamaged fruits causing great harvest losses (Sasaki and Sato, 1995). The fruit fly D. suzukii is a highly polyphagous invasive pest with many host plants both cultivated and wild soft-skinned fruits, allowing it to spread rapidly and with high dispersal rate (Cini et. al., 2014). Damage is caused by larvae feeding within the soft tissue of the fruits. Subsequently, secondary fungal or bacterial infections may further

Oddelek za varstvo rastlin, Kmetijski inštitut Slovenije, Hacquetova ulica 17, 1000 Ljubljana, Slovenija. *Corresponding author: spela.modic@kis.si 
promote fruit deterioration. Economic losses of fruit production were reported for USA (California) $\$ 390$ million (Bolda et.al, 2010) and Italy (Trentino) $€ 3.3$ million (Ros et. al., 2013).

Chemical control methods for fruit flies have low efficiency (Bruch et. al., 2011). Therefore, biological control using parasitoids might play an important role as an alternative to synthetic chemical insecticides. For effective use in biological control programmes it is important to promote the use of indigenous natural enemies from the newly invaded areas, also due to strict regulations of European legislation (Barratt et al., 2018; Van Lentern, 2012). Most studied larval parasites of Drosophila were of the genera Leptopilina and Asobara and the pupal parasites Spalangia, Pachycrepoideus and Trichopria (Fleury et. al., 2009). A generalist pupal parasitoid Pachycrepoideus vindemmiae (Rondani, 1875) (Hymenoptera Pteromalidae), a major natural enemy of $D$. melanogaster (Martelli), was recently found to be also associated with $D$. suzukii in USA (Brown et al., 2011) and Europe (Rossi Stacconi et al., 2013; Chabert et al., 2012, Knoll et al., 2017). European pupal parasitoid Trichopria drosophilae was also found to attack and develop on D. suzukii (Mazzetto et al., 2016). The fact that both parasitoids attack the invasive spotted wing drosophila was also reported in Italy (Rossi Stacconi et al., 2013), Spain (Gabarra et al., 2014) and California (Wang et al., 2018). Further, they could be adapted to different climatic conditions. The aim of this survey was to identify the presence of indigenous D. suzukii parasitoid species in Slovenia (Central Europe) via field surveys.

\section{MATERIALS AND METHODS}

\subsection{Insect rearing}

Studies were conducted at the Agricultural Institute of Slovenia, in Ljubljana, Slovenia. Flies of D. suzukii were reared in $30 \times 30 \times 30 \mathrm{~cm}$ plastic insect rearing cages (BugDorm-1; Mega View Science, Taiwan) in a growth chamber in D: L cycles of $14: 10 \mathrm{~h}$ at $21^{\circ} \mathrm{C}$ and $77 \pm$ $3 \%$ relative humidity. The flies were provided with tap water and solid artificial food medium ( $20 \mathrm{~g}$ agar, $20 \mathrm{~g}$ sugar, $10 \mathrm{~g}$ wheat flour, $50 \mathrm{~g}$ dry baker's yeast, $500 \mathrm{ml}$ tap water, $400 \mathrm{~g}$ grated organic apples, $500 \mathrm{ml}$ organic apple juice, $50 \mathrm{ml}$ apple vinegar and $4 \mathrm{~g}$ nipagin (methyl 4-hydroxybenzoate, Sigma-Aldrich).

\subsection{Preparation of sentinel traps}

Larval and pupal D. suzukii parasitoids were sampled using sentinel traps as described elsewhere (Miller et. al., 2015; Rossi Stacconi et. al., 2013) with small modification: Plastic cups $(125 \mathrm{ml})$ containing fresh banana slices (60-70 g) were exposed for 1 to 3 days to D. suzukii (Diptera: Drosophilidae) flies in rearing cages. During that time the females laid eggs in banana slices. Once removed from the oviposition, infested banana slices were maintained for 5 to 7 days in the laboratory at room temperature to allow development of larvae and pupae. Afterward the larvae and the remainder of the eaten banana slices were transferred into new $500 \mathrm{ml}$ plastic containers and enriched with $(10 \mathrm{~g})$ artificial food medium for drosophilids. In each infested plastic container one dental cotton tampon (Tosama, Domžale, Slovenia) was placed for absorbing excess liquid of contents. At the end containers were covered with mesh dimensions $(0.8 \times 0.8 \mathrm{~mm})$ through which parasitoids could pass but not the flies. Each container was placed inside a funnel trap (green lid/green funnel/transparent bucket; catalogue number: 30201) from Pherobank, Netherlands and exposed to natural enemies in the environment.

\subsection{Laboratory and field observation}

Sentinel traps were set to a height of 1 to $1.5 \mathrm{~m}$ from the ground into raspberry plants. After 5 to 7 days of field exposure, the containers with the potentially parasitized SWD larvae and pupae were removed from the funnel trap and additionally coated with fine mesh gauze that prevents the passage of the parasitoids. They were transferred to a growth chamber and held at $22{ }^{\circ} \mathrm{C}$ and $77 \pm 3 \%$ relative humidity, $14: 10 \mathrm{~L}: \mathrm{D}$ photoperiod and observed weekly for another eight weeks for emergence of parasitoids. In central Slovenia (Ljubljana) three sentinel traps were field-exposed simultaneously for one week to natural fauna from the second half of June to October in 2018. 


\section{RESULTS AND DISCUSSION}

The pupal parasitoid Trichopria drosophilae (Hymenoptera: Diapriidae) and the larval parasitoid Leptopilina heterotoma (Hymenoptera: Figitidae) were recorded attacking spotted wing drosophila for the first time in Slovenia in the summer 2018 in Central Slovenia (Ljubljana). Traps baited with D. suzukii larvae or pupae exposed in the field were attacked with both species during 23 to 27 July $2018\left(30^{\text {th }}\right.$ calendar week). The peak flight of $L$. heterotoma in a growth chamber was recorded one month later $23^{\text {th }}$ August 2018, when more than 30 individual emerged from larvae D. suzukii. Only two individuals of Trichopria drosophilae were caught on sentinel traps.

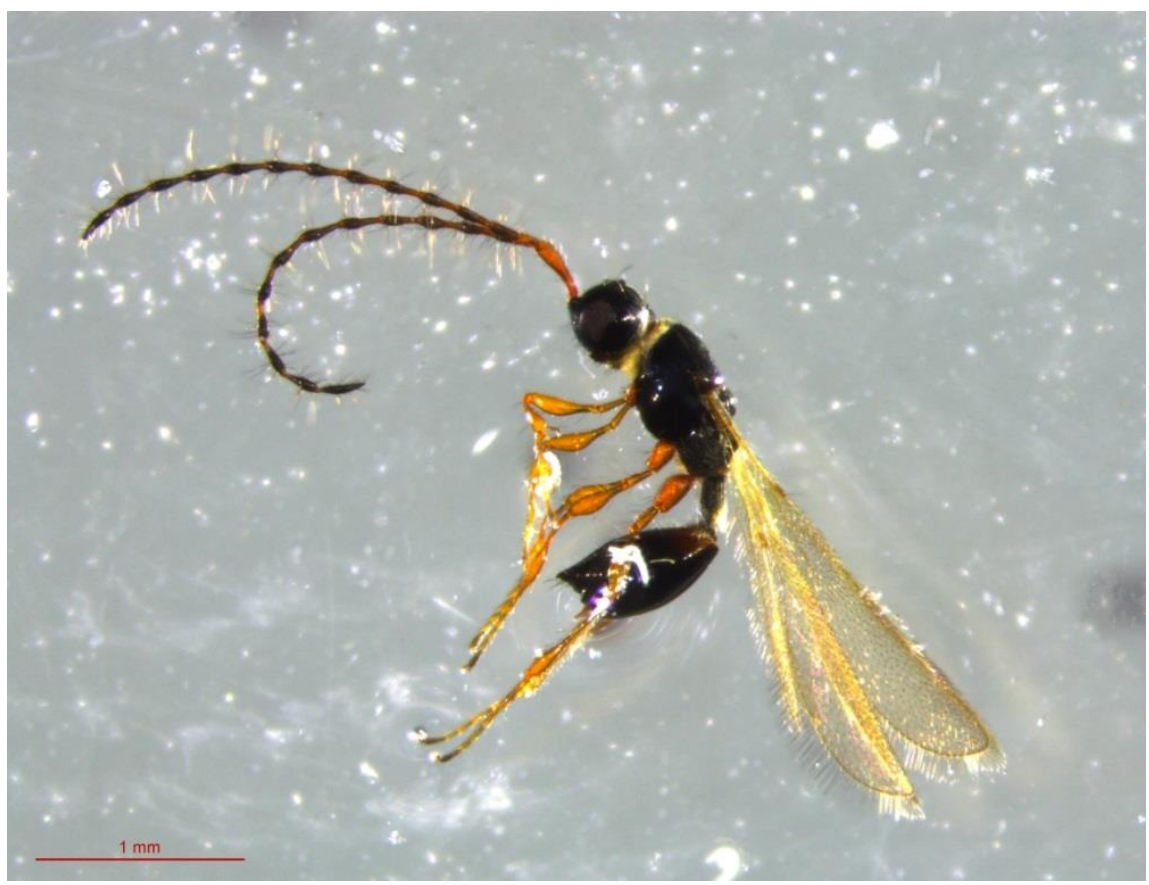

Figure 1: Trichopria drosophila (Perkins, 1910) (Hymenoptera,Diapriidae)

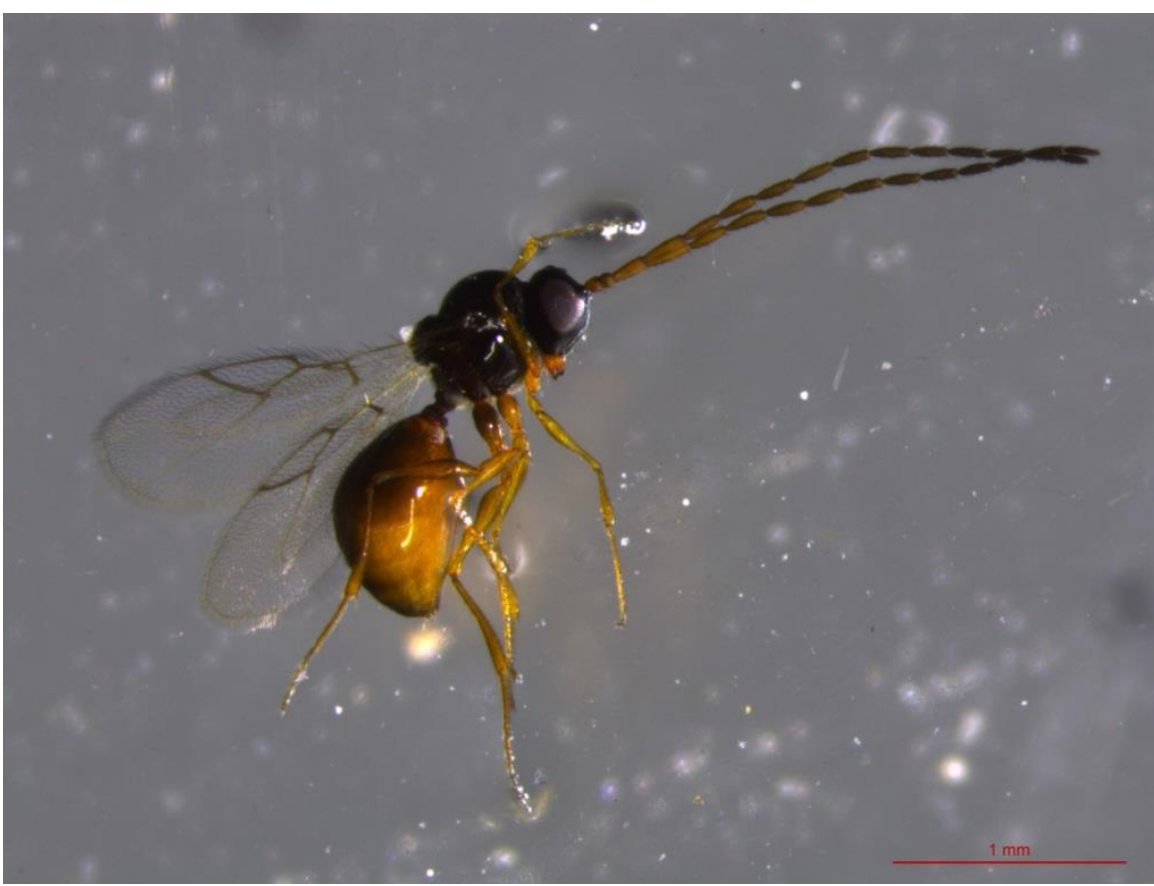

Figure 2: Leptopilina heterotoma (Thompson, 1862) (Hymenoptera,Figitidae) 
A lot of parasitoids are reported to attack various Drosophilidae species, and the majority of them are larval parasitoids such as the most generalist parasitoid Leptopilina heterotoma (Fleury et al., 2009), which we also found parasitizing $D$. suzukii in our region. It is a solitary koinobiont parasitoid that attacks first and second stages of Drosophila larvae (Fleury et al., 2009).
The cosmopolitan pupal endoparasitoid Trichopria drosophilae attacks many Drosophilidae species, including $D$. suzukii, and could potentially be a good biological control agent for this important pest (Chen et al., 2018). It is idiobiont parasitoid whose host range is known to be limited to Drosophilae (Wang et al., 2016).

\section{CONCLUSION}

This paper contributes to the knowledge of the wide spread of native beneficial organisms of $D$. suzukii such as the paleartic larval parasitoid Leptopilina heterotoma and cosmopolitan pupal endoparasitoid Trichopria drosophilae. Results promote awareness of the importance of further field studies to investigate parasitoid adaptation to local agroecosystems and its potential for wider use in biological control.

\section{ACKNOWLEDGEMENTS}

This work was financially supported by the Administration of the Republic of Slovenia for Food Safety, Veterinary Sector and Plant Protection and Slovenian Ministry of Agriculture, Forestry and Food.
The authors wish to thank for identification of specimens to prof. Dr. Vladimir Žikić and Dr. Marco Valerio Rossi Stacconi.

\section{REFERENCES}

Barratt, B I. P., Moran, V. C., Bigler, F., van Lentern, J. C. (2018). The status of biological control and recommendations for improving uptake for the future. BioControl, 63, 155-167. https://doi.org/10.1007/s10526-017-9831-y

Bolda, M., Goodhue, R.E., Zalom, F.G. (2010). Spotted wing drosophila: potential economic impact of a newly established pest. Agricultural and Resource Economis, 13, 5-8.

Bruck, D.J. Bolda, M., Tanigoshi, L., Klick, J., Kleiber, J., Defrancesco, J., Gerdeman, B., Spliter, H. (2011). Laboratory and field comparisons of insecticides to reduce infestation of Drosophila suzukii in berry crops. Pest Management Science, 67, 1375-1385. https://doi.org/10.1002/ps.2242

Chen, J., Zhou, S., Wang, Y., Shi, M., Chen, X., Huang, J. (2018). Biocontrol characteristics of the fruit fly pupal parasitoid Trichopria drosophilae (Hymenoptera: Diapriidae) emerging from different hosts. Scientific reports, 8, 13323. https://doi.org/10.1038/s41598-018-31718-6

Cini, A, Anfora, G., Escudero-Colomar, L.A., Grassi, A., Santosuosso, U., Seljak, G., Papini, A. (2014). Tracking the invasion of the alien fruit pest Drosophila suzukii in Europe. Journal of Pest
Science, $\quad$ 87: 559-566. https://doi.org/10.1007/s10340-014-0617-z

Cini, A., Loriatti, C., Anfora, G. (2012). A review of the invasion of Drosophila suzukii in Europe and a draft research agenda for integrated pest management. Bulletin of Insectology, 65(1), 149160.

De Ros, G., Anfora, G., Grassi, A., Loriatti, C., (2012). The potential economic impact of Drosophila suzukii on small fruits production in Trentino (Italy). IOBC/WPRS Bulletin, 91, 317-321.

Fleury, F., Gibert, P., Ris, N. \& Allemand, R. (2009). Ecology and life history evolution of frugivorous Drosophila parasitoids. In: Prevost, G. (Ed.): Advances in Parasitology, Vol 70: Parasitoids of Drosophila, 3-44. https://doi.org/10.1016/S0065308X(09)70001-6

Gabarra, R., Riudavets, J., Rodriguez, G.A., PujadeVillar, J., Arno, J. (2014). Prospects for the biological control of Drosophila suzukii.BioControl, 60(3), 331-339. https://doi.org/10.1007/s10526-014-9646-Z

Knoll, V., Ellenbroek, T., Romeis, J., Collatz, J. (2017). Seasonal and regional presence of hymenopteran parasitoids of Drosophila in Switzerland and their ability to parasitize the invasive Drosophila suzukii. 
Scientific Reports $\quad$ 7, 40697. https://doi.org/10.1038/srep40697

Mazzetto, F., Marchetti, E., Amiresmaeili, N., Sacco, D., Francati, S., Jucker, C., Dindo, ML., Lupi, D., Tavella, L. (2016). Drosophila parasitoids in northern Italy and their potential to attack the exotic pest Drosophila suzukii. Journal of Pest Science, 89, 837-850. https://doi.org/10.1007/s10340-0160746-7

Miller, B., Anfora, G., Buffington, M., Daane, K. M., Dalton, D. T., Hoelmer, K. M., Walton, V. M. (2015). Seasonal occurrence of resident parasitoids associated with Drosophila suzukii in two small fruit production regions of Italy and the USA. Bulletin of Insectology, 68(2), 255-263.

Rossi Stacconi, M.V., Grassi, A., Dalton, D.T., Miller, B., Ouantar, M., Loni, A., Ioriatti, C., Walton, V.M., Anfora, G. (2013). First field records of Pachycrepoideus vindemiae (Rondani) (Hymenoptera Pteromalidae) as a parasitoid of Drosophila suzukii in European and Oregon small fruit production areas.- Entomologia, 1(e3), 11-16.

Sasaki, M., Sato, R. (1995). Bionomics of the cherry drosophila, Drosophila suzukii Matsumura
(Diptera: Drosophilidae) in Fukushima prefecture (Japan). Annual Report of the Society of Plant Protection of North Japan, 46, 164-172.

Seljak., G. (2011). Spotted wing Drosophila, Drosophila suzukii (Matsumura), a new pest of berry-fruit in Slovenia. Sadjarstvo, 22 (3), 3-5.

Van Lentern, J.C. (2012). The state of commercial augmentative biological control: plenty of natural enemies, but a frustrating lack of uptake. BioControl 57, 1-20. https://doi.org/10.1007/s10526-011-9395-1

Wang, X.G., Kaçar, G., Biondi, A., Daane, K.M. (2016). Life-history and host preference of Trichopria drosophilae, a pupal parasitoid of spotted wing drosophila. Bio Control, 61, 387-397. https://doi.org/10.1007/s10526-016-9720-9

Wang, X.G., Serrato, M.A., Son, Y., Walton, V.M., Hogg, B.N., Daane, K.M. (2018). Thermal Performance of Two Indigenous Pupal Parasitoids Attacking the Invasive Drosophila suzukii (Diptera: Drosophilidae). Environmental Entomology, 47(3), 764-772. https://doi.org/10.1093/ee/nvy053 